КУЛЬТУРОЛОГИЯ

UDC $115+141+72$

\title{
Invention of the future in project-time. An imaginary "encounter" between Georg Simmel and Henri Bergson, and its significance for architecture
}

\author{
P. Bojanićl, ${ }^{1,2}$ E. S. Cherepanova ${ }^{2}$ \\ ${ }^{1}$ University of Belgrade, \\ 45, ul. Kraljice Natalije, Belgrade, 11000, Serbia \\ ${ }^{2}$ Ural Federal University named after the first President of Russia B. N. Yeltsin, \\ 51, pr. Lenina, Ekaterinburg, 620083, Russian Federation
}

For citation: Bojanić P., Cherepanova E. S. Invention of the future in project-time. An imaginary "encounter" between Georg Simmel and Henri Bergson, and its significance for architecture. Vestnik of Saint Petersburg University. Philosophy and Conflict Studies, 2020, vol.36, issue 1, pp.131-140. https://doi.org/10.21638/spbu17.2020.111

The article addresses the reconstructed dialogue with the texts of G. Simmel (G. Simmel "Untersuchungen über die Formen der Vergesellschaftung"; "Über räumliche Projekten sozialer Formen") and H. Bergson (H. Bergson "Histoire de l'idée de temps") in order to analyze the question of how the design/creation of the future was understood by these philosophers, and how this question can be interpreted today. We would like to present some conditions and difficulties in revealing the future and the temporal nature of any project. First, we would like to insist on a weakness in languages spoken by a great number of people, which is that the future is difficult to linguistically stabilize and document: German and English do not have a future tense, using instead auxiliary verbs, "werden" (to become), "will"/be going to". The study of the project as an intellectual (intention, idea, concept) and social phenomenon (design as a social action) allows us to illustrate how the future (project) becomes a task of activity in the present. The project transfers or shifts (Simmel) the future time to space which is always ready for the perception of projections, and is also an opportunity to organize future joint actions. We will argue that when the project is executed, when it is no longer - there is no longer any future. The project thus ensures the future. Or, to achieve complete circularity, we will introduce a third element: without the future, a group or a "we" cannot possibly exist. In our text, we would like to unreservedly insist that the idea of a project, or perhaps a sketch of any

* Исследование выполнено при поддержке гранта Российского научного фонда (проект № 19-18-00342).

(c) Санкт-Петербургский государственный университет, 2020 
future theory of the project (or concept), has already been provided at the beginning of the last century within an imaginary encounter between Henri Bergson and Georg Simmel.

Keywords: project, time, future, Henri Bergson, concept.

To begin with, we would like to strengthen the ties among time (specifically, the future), action, and the community. Let us imagine and first analyze a conference or summer school taking place, and this text being read out there. Both the text and the conference or summer school have been planned well in advance. At the time when such a summer school is being planned, imagine all the chatter back and forth among the imaginary organizers and participants - at this point, there is a clear intention to make the conference happen (let us call it "empty intention"1). Vague notions, intentions, and conceptions (concepts ${ }^{2}$ ) of the imaginary conference at the University of Ekaterinburg (the space, location) formulated and constructed over the course of, let us say, a year, through various communal acts, as a complicated project (with documents, a budget, money, orders, a work plan, schedule, timing), all have to come together over the course of a few days by a given date.

Then, later, when it does happen, people are taking part, talking, discussing both the subject of the conference and the conference itself - it ceases to exist in the future, that is, as merely a project yet to be executed and becomes a "(ful)filled intention" (or just intention). In taking place, the conference has a new modality. All the previous planning has to happen by holding us together as a group with a given task. The conference taking place which was previously in the future - has in one way or another replaced the concept and project. A group of people jointly designed and organized the transmission of a series of amorphous mental entities to become this (imaginary) conference, that is, a set of communal social acts and facts. The future has conformed to the present.

We do not need to list all the consequences of this future that have just taken place, but certainly the conference, as a social fact or repertoire of social facts has eliminated the prior time of project design and execution. "Eliminated time" actually represents the erasure of temporality in the project, a temporality only possible within the project - and this is what we are above all interested in showing ${ }^{3}$. Let us formulate our claim in reverse: when the project is no longer - there is no longer any future. The project ensures the

${ }^{1}$ Husserl speaks of an intentionally empty horizon (intentionaler Leer-horizont), an absence to be filled (eine ausfüllende Leere) (E. Husserl, Analysen zur passive Synthesis (1918-1926), Cf. [1]).

${ }^{2}$ Speaking of the "concept" in his two semesters dedicated to time, Bergson neglects to make use of something that might more precisely explain his intention. The "empty concept," has a history from Kant to Sartre. As opposed to the "authentic" concept, the "empty concept" refers to something fictitious that has no corresponding "reality." In the commentary of his translation of Aristotle's "Peri Ermenias," Boethius recognizes the existence of empty concepts. Alain de Libera translates Boethius "intellectus" as "concept," because in Boethius "conceptio" and "conceptus" are synonymous with "intellectus." "Boethius was apparently the first to recognize that there is such a thing as an empty concept, i.e. intellections that have no corresponding real subject, such as centaurs and chimeras or ones invented by poets" [Or Boèce est, évidemment, le premier à reconnaître qu'il y a des concepts vides, i.e. "des intellections qui ne correspondent pas à une réalité sujet, comme celles que les poètes ont façonnées, centaures ou chimères"] [2, p.418].

${ }^{3}$ Divine creation, the various acts of Adonai in the course of creating the world, only partially satisfy the criteria to be named a project or the product of a project. By thinking it (conceptualizing it) or simply saying it, Adonai has already created. It is as if there were no process of creation or time of execution of the project. 
future. Or, to achieve complete circularity, let us introduce a third element: without the future, a group or a "we" cannot possibly exist.

Once the imaginary conference is underway, the organizers and participants assess whether the project corresponds to the concept that preceded it. Was the conference project executed better than thought (we might say "it is going better than expected")? Or has it perhaps failed to meet its idea? What does a failed project mean? Does not the meaning of the word 'project' (to present something in advance, to pitch) already imply that every project is necessarily failed? The very possibility of comparing this conference with others, both ideal and ones taken place, opens up the possibility of immediately constructing a next project and with it the future as such. Thus, as soon as it appears that a project has been executed ${ }^{4}$ and ceases to exist, a new project or many projects appear on the horizon. If several protocols, such as "possibility," "horizon" 5 and "imagination" ("as if") are in some way "mingled" and "entwined," would that be enough to show that the basic mode of project temporality - the future, what is yet to come (avenir in French) or what is to follow - has ultimately been revealed? ${ }^{6}$ If "the future" is revealed within an imaginary distance between the concept and project, between two words or notions always difficult to differentiate, does then this modality of time have special status in the "time - space" relation? How much future is there necessarily in space? Better still, is future more connected to space than is, for example, the past?

By presenting a number of conditions for revealing the future and the temporal nature of the project, we would like to mention a few difficulties. We would like to provisionally insist on a weakness found in certain languages spoken by a great number of people, which make the future difficult to linguistically stabilize and document: German and English, for example, do not have a future tense, using instead auxiliary verbs, "werden" (to become), "will" / "be going to."

The first condition for revealing the future refers to the pronoun 'we.' Whence 'we' and how is it possible? 'We' who produce certain social acts as part of a project (residents of a city, for example, who pass by each other, live side by side, tolerate one another, etc. ${ }^{7}$ ) also construct its following, new projects. 'We' is always what is left over from a project just completed and what is always altered and constituted anew ('new' or 'sudden' is always both possible and impossible). The future is implicitly present in each expression of a given state that is addressed to some other or others (individuals): if one promises something to someone, there is an assumption of time needed to make good on the promise ${ }^{8}$. Furthermore, every address to another is simultaneously the expectation of a reaction

${ }^{4}$ With 'execute,' English is wonderfully helpful in this case: where other European languages use some variation of 'realized' for the operation of bringing something to fruition, English more commonly uses a word meaning to kill, to remove from existence.

${ }^{5}$ These two words speak to the constitutive primacy of the future and evoke the phenomenological hermeneutic method.

${ }^{6}$ Does the future arrive or follows and moves ahead? How can we describe what has yet to happen? Does one wait for the future, or is it constructed and anticipated? Projection and design is an artificial operation of preparation for what is to come thus reducing the uncertainty of "what has yet to arrive".

7 In Hebrew, making time has the same root with the invited one, with hospitality. The invitation produces the future.

${ }^{8}$ Interestingly, when constructing his argument on the difference between performative and constative, John Austin never speaks of time implied in any successful performative act. If I promise you that I will replace your bike tire, it is not enough that in uttering this sentence I have performed an act of obligation. Also implied is the agreement of place and time by when I will do so. A promise necessarily introduces time. 
and reciprocity, which is also always temporally conditioned (between the greeting 'hello' and the responding 'hello, there is an interval; between an initial Viber message and the response, there is a period in which perhaps another question is being asked of a third). "Give me time" or "take your time" or "I will buy time" can confirm the future as an interval in which various actions are to be performed. Reticence to answer or address someone else is a type of negative social act. Finally, the still complicated and ill-defined position of a head or leader in a democracy opens the act of ordering (or consulting, suggesting, advising) to future time and the production of inequality 9 .

For a group to potentially remain together, confirm its own 'we-mode' (for two to remain together, since love is above all continuously projected) and preserve its 'co-presence' (such as to meet and work together at next year's conference), various project operations (co-regulations) have to be introduced: correcting mistakes in the production of social acts, exclusion of the undisciplined, repetition, forecasting, differentiation of the possible from the impossible, insistence anew, insistence on the new, amendments, etc.

The second condition also refers to the pronouns 'we' or 'us', referring to an important connection between the future and space (co-presence or co-present implies "the local structure of we-space itself" [4, p.646]). It is as if the future is primarily that form of time allowing and ensuring a connection between time in general and space. The simple fact of my passing time unfolding inseparably from my body extending in space can be entirely simultaneous with the simple fact of your passing time unfolding in your body extending in space. Two temporalities and two spatialities that do not intermingle are always recognized in the present. However, physical (and not only physical ${ }^{10}$ ) co-present contact always introduces the aspect of the future: orientation and location (and dislocation, a term from architect P. Eisenman). Based on this, my existence in the future is directly dependent on the space I could occupy in that future with others. The architectural protocol as such does not necessarily appear with the invention of space, but with the introduction of "our" time (or "our" future) into space.

The various problems that occur in the course of our common or simultaneous penetration of a group into a given location and its duration there, its co-existence or common living in a single place, all demand a necessary reconstruction of the connection between architecture and philosophy (or sociology) ${ }^{11}$. The first task or epistemological operation would consist of constructing an architectural terminology that meticulously follows the repertoire of various gestures (steps, moments, points, sequences) made in the course of

[We can tell this from the joke of the husband saying to his wife: "if a man promises to clean out the garage, he is going to clean out the garage; there is no point in reminding him every six or seven months!"

${ }_{9}$ Alexandre Kojève gives a very simple example, even if his conclusion is entirely insignificant. The authority of the creator of the project (the subject) is incidental compared to the authority of the project itself that forms the group and has simultaneously been its real creator: "Let us consider a familiar example. A band of kids gather to play. One of these kids proposes to go and steal apples from the orchard next door. Immediately, by doing so, he casts himself in the role of the band's leader. He became this leader because he saw further (plus loin) than the others, because it was he alone who thought out a project, while the others did not manage to get beyond the level of immediate facts" [3].

${ }^{10}$ Does Skype (Viber, WhatsApp, or Signal) co-present mean "present" and does it mean common space? Also, does telepathy contain a future moment or an announcement of future time?

11 This reconstruction should be constantly thematized in order to compare and harmonize two different productions of knowledge. Take, for example, the question of Hashim Sarkis, curator of the "Architecture Biennale 2020": "How will we live together?" It is a remake of the seminar held by Roland Barthes in 1976/77, "Comment vivre ensemble?" 
a communal taking of space (from concept and project to object and the material). How do we name the various gestures and provide an order of notions that would correspond to the archeology of philosophical and historical notions? Parallel to this, a new reading of philosophical texts from an architectural perspective allows for correcting their logic and establishing new connections between the future (time) and space. The following is an example: at the same time that Bergson is delivering his seminars in which he thematizes time (leaving aside the equally important question of how he even enters the abstract problem of time), Georg Simmel publishes his 1903 text "Über räumliche Projektionen sozialer Formen" [5, p. 201-220] ${ }^{12}$. We would like to unreservedly insist that the idea of a project, or perhaps a sketch of any future theory of the project, has been constructed at this time, across an imaginary exchange between Bergson and Simmel. Simmel's title could be a translation and addition to a well-known expression from Kant, which also requires intervention if we introduce the dimension of time, that is, the future. Simmel calls the transfer or shift of social forms "spatial projection." If we dissect this phrase, we have social forms launched from somewhere or projected into space. Casting social forms into space is actually a temporal operation that relies on social forms maintaining themselves or existing only in space (these social forms are actually constructions connecting people and protecting relations among them, maintaining their or our 'we'). However, by combining this protocol with a 1908 sentence by Simmel, written in the style of John Searle ("The boundary is not a special fact with sociological consequences, but a sociological fact that forms itself spatiality" [6, p. 697]), it becomes clear that social acts in fact establish space. Space is always already social space, constituted in time yet to come. The project (or projection / design) actually brings future time to space. Only in this way is the construction of the social complete. Agents or subjects occupy, or make space, by projecting their mutual relations. Simmel cites Kant's sentence from "Paralogisms" several times ("Criticism of the fourth paralogism of transcendental psychology;" the ever-relevant passage on the difference between idealism and realism). Speaking of space as representation, Kant says:

This perception thus represents (staying for now only with outer intuitions) something real in space. For first, perception is the representation of a reality, just as space is the representation of a mere possibility of coexistence [Diese Wahrnehmung stellt also, (damit wir diesmal nur bei äusseren Anschauungen bleiben) etwas Wirkliches im Raume vor. Denn erstlich ist Wahrnehmung die Vorstellung einer Wirklichkeit, so wie Raum die Vorstellung einer blossen Möglichkeit des Beisammenseins] [7, p.428].

Space is really a representation of the mere possibility of coexistence. The phrase can also be rendered into English as "possibility of being together." Only in this one place does Kant use this word, so difficult to translate, Beisammenseins - "being next to one another." The social is here only implicit, but the phrase provides a primer for Simmel's suggestion that space is always ready to accept any future projection.

The third condition - which is implicitly the first necessary condition to give the future form - refers to the connection between the concept and expression. Thus, prior to the condition in which the group constitutes the project in the future in order to sustain itself in the present (which is a fundamental characteristic of strategy - "having a pro-

\footnotetext{
${ }^{12}$ Along with some other writing, it will be incorporated into a chapter of his Sociology where he thematizes the notion of space.
} 
ject"), and prior to the second condition in which social forms penetrate into space all at once, constituting it, there is a complicated attempt to conceptualize the concept through expression and expressivity. In the introductory session of his second seminar on time, on 5 December 1902, Bergson differentiates relative and absolute knowledge. English pronunciation provides him (whose mother was English) with an example. After concluding that his English is completely contaminated by French and "in service to French" [en function du français], Bergson says:

What would it take to have absolute knowledge? It would be necessary to be transported to England, live among the English, living an English life, immersed in the flow of English expression. $\langle\ldots\rangle$ Relative knowledge means knowing from outside of what one is learning; relative knowledge of English expressions is having knowledge outside England, being and residing in France. It means knowing English in service of French elements and expressions. On the other hand, absolute knowledge of English expressions is knowing not from the outside, but from within. In order to have such absolute knowledge of expressions, I must not stay at home, I must go to England. I can then learn to use not my home expressions, but those foreign, know them in themselves, as the philosophers say [Que faudrait-il pour en avoir une connaissance absolue? Il faudrait me transporter en Angleterre, il faudrait vivre avec des Anglais, vivre de la vie anglaise, il faudrait me plonger dans le courant de la prononciation anglaise; $\langle\ldots\rangle$ Connaitre relativement c'est connaittre du dehors, c'est être en dehors de ce qu'on apprend; connaître relativement la pronunciation de langlais, c'est la connaître étant hors de l'Angleterre, étant en France et restante en France; cést connaître l'anglais en function déléments de prononciation française. Au contraire, connaître absolument cette prononciation, cést la connaître non pas $d u$ dehors, mais $d u$ dedans. Pour connaître cette prononciation absolument, il ne faut pas que je reste chez moi, il faut que jaille en Angleterre; je connais alors la prononciation non plus de chez moi, mais chez elle, en soi, comme dissent les philosophes] [8, p.18-19].

This is a magical passage from a man who was well-nigh bilingual, yet insisted on a specific difference that concerns a few crucial notions that frame any possible knowledge about time: a) precision (a register we would today easily confuse for perfection ${ }^{13}$ ) that is in harmony with others and concerns socialization or the social (Bergson uses the phrase "la vie sociale" [8, p. 134-135]). It includes a locality that surpasses people who live in a given location. Bergson differentiates England, life with the English and English life; b) concept (since Bergson's seminars are really about the construction of the concept, such as the concept of knowledge of expression ("absolute knowledge of expression" [connaître cette prononciation absolument]); c) "active expression" (the phrase is ours) (since the concept for Bergson is "an invitation to action" [une invitation à agir] or "above all a suggestion of possible action" [avant tout une suggestion d'une action possible] [8, p. 64], meaning c1) action, and c2) expression (the imperative is to express oneself absolutely - to express the concept). To know - to know absolutely - means to express oneself absolutely, i. e. correctly.

${ }^{13}$ Bergson ascribes the invention of precision of articulation and demonstration to the Greek genius. Speaking also of perfection in the introductory session, he writes: "should I wish to arrive at perfection, I would have to continue indefinitely, into infinity - when I might reach perfect reproduction - but this could never truly take place" [et si je veux arriver à la perfection, il faudra que je continue sans fin, à l'infinijobtiendrai la reproduction parfait —, mais elle ne sera jamais véritablement réalisée] [8, p. 30, 88, 90]. The perfect, which is good and done, is not the same as the realized. The project substantively resists the complete or finished, which as such definitely belongs to the past; the project is ceaseless. 
Why is the concept ("le concept" or "la pensée conceptuelle" — words which Bergson uses interchangeably) ${ }^{14}$ important for Bergson, and why is the theory of the concept constructed by Bergson really an introduction into an imaginary never-written study of the project? ${ }^{15}$ Time and duration are what cannot be expressed through concepts [par des concepts ${ }^{16}$. But time as future begins with naming, with language and expression of what is initially present in the mind (a l'esprit).

I am saying that it (the noun, substantive) first refers to the individual. When I say 'man' or 'table', it is in the singular, individual form that the concept presents itself to the mind [Je dis qu'il (le nom, le sustantif) exprime d'abord l'individuel. Quand je dis: l'homme, la table, c'est une conception individuelle, un concept d'individu que se présente d'abord à l'esprit] [9, p. 126].

If time as such cannot be rendered or expressed in language ("there is an interval that remains unexpressed" [il y a un intervalle qui reste inexprimé]), language as well as the expression of everything else begins in the future tense.

Action, as the actual beginning of the project (and action is in opposition to perception, according to Bergson [8, p. 70]), and "throws time back outside" [9] is regulated by the precision and rigor of expression in uttering the concept $\mathrm{t}^{17}$.

Among else, man is a speaking being, a social being, and will assign words to concepts. Being much more malleable than any corporeal approach he could take, the word will also render the concept much more malleable and flexible. Man will make use of the word not only to speak to others, but to speak to himself [L'homme est, en outre, un être qui parle, un être sociable, et ce concept il va le designer par un mot, et ce mot étant un signe beaucoup plus maniable que ne le serait l'attitude corporelle prise par lui, ce mot va render le concept beaucoup plus maniable, aussi plus mobilizable. Il se servira du mot non seulement pour parler aux autres, mais pour se parler à lui-même] [8, p. 72].

The production of concepts is an entirely artificial, human thing, as is the project. "The concept has its origin in action and is above all an instrument for action" [concept a son origine dans l'action et il est avant tout un instrument d'action] ("a concept expresses an

14 The following academic year, Bergson says the following: "the concept, which is to say, the general idea, simple, abstract" [le concept, c'est-à-dire l'idée générale, simple, abstraite] [8, p. 69, 125].

${ }^{15}$ What philosophers call the concept, says Bergson "that is, the idea, the representation, that which can be in its entirety intellectually manipulated" [c'est-à-dire l'idée, la représentation, en tant qu'elle a été préparée entiérement pour la manipulation intellectuelle] occurs in three ways or through three operations. The origin of this manipulation lies in "the faculty of the intellect par excellence" [la faculté intelectuelle par excellence] or "ability to form concepts and think in concepts" [faculté de former des concepts et de penser par concepts] [8, p. 56, 60-61].

16 "The conclusion is this: if ever there were something that could not be expressed through concepts, if ever there were something defiant of all symbolic representation - it is what we will be speaking of this year: time. We will be exploring different theories of time and duration" [La conclusion est celle-ci: s'il y a quelque chose qui ne puisse pas sexprimer par des concepts, s'il y a quelque chose qui soit réfractaire à toute espèce de représentation symbolique, c'est precisément l'objet dont nous allons parler cette année, c'est le temps, c'est la durée, don't nous allons examiner les différentes théories] [8, p.77].

${ }^{17}$ If we take precision as our guide, we must necessarily consider as inexistent anything that is not expressible with perfect clarity, not to mention that which is not expressible at all" [Là où on tient à la précision avant tout, on est amené necessairement à considérer comme inexistant ce qui n'est pas exprimable avec une précision parfaite, à plus forte raison ce qui n'est pas exprimable du tout] [8, p.91, 94, 95]. Analyzing Parmenides' poem on pages 94 and 95, Bergson insists that what cannot be expressed is not real, although he is aware that "becoming" [devenir] is always difficult to express. It is incredible how Deleuze lifted this idea many years later. 
action" [un concept exprime une action]) [8, p.73]. Action creates concepts and concepts draw on action. The second operation marks the birth of the project.

Bergson offers no further explanation of "speaking to himself" [pour se parler à luimême], despite this being a substantive aspect of speech addressed to others. It is thus possible to speak of a further construction or speculation about a project that is individual or mine alone. In any case, the idea that it is possible to speak to oneself is deduced from speech addressed to others and implying their response. Speaking to others is to invite them to action, or better still, joint action. Several possibilities follow from this: first, that I cannot express something on another's behalf (I can help and complete someone's words or sentences, I can translate, but never replace another in "expressing a concept"). Second, precise expression implies retaining those who hear me (as well as those who have yet to hear me) in the given space, preserving our common use of the space. Third, expressing the concept would be equal to expressing one's own concept or one's self - expressing oneself is expressing one's concept. This means gaining time in anticipation of others' responses, which is to say, common construction of projects and the future ${ }^{18}$. Fourth, expressing well is necessarily compulsive and pressing (Zeitnot, urgency, priority, prevention, etc. $)^{19}$.

All concepts have, more or less, a practical goal, and all concepts are our questions addressed to reality, from a subjective standpoint, regarding the attitude we should adopt towards it and it towards us. A concept is a rubric, a class into which we enter an object. Finding the right class for each object, asking of it whether it go here or there, ultimately means asking it what it is in relation to us, what we can make of it [Tout concept a, plus ou moins, une destination pratique, tout concept est une question posée par nous à la réalite, au point de vue relative, à l'attitude que nous devons prendre vis-à-vis d'elle ou quelle prend vis$\grave{a}$-vis de nous; un concept cést une rubrique, une classe dans laquelle nous faisons rentrer un objet. Chercher dans quelle classe un objet peut rentrer, lui demander s'il est ceci ou cela, c'est au fond lui demander ce qu'il est par rapport à nous, ce que nous pourrions faire de lui] [10, p. 43].

At the point when the word 'object' appears (which belongs to the same semantic group as the word 'project'), all the necessary conditions for constructing the future are brought together. What, then, is the object, and what is its connection with the project or "the architectural project?" 20

${ }^{18}$ How does a turn signal work in traffic? The conception or set of conceptions about the functioning of the turn light in traffic, recognizing traffic rules, driving technique, as well as holding various concepts about movement in space (left, right, forward, backwards), all draw us into the operation of movement. I have the intention to turn left, which I signal thus projecting in time my future left turn. Signaling (singular or plural) is an address to others, it is a call for us to jointly consider my intention. By their joining into this consideration, it becomes a spatial projection of (one or more) social forms or social facts.

${ }^{19}$ Consider the elaboration by the Japanese architect Tadao Ando: "Question: you were a boxer? Tadao Ando: it was a question of survival. I had to earn money for my grandmother who raised me in a workingclass neighborhood in Osaka. There was a boxing club across the street. I thought I could win. I had a trial and went professional. Box consists of being forced to fight someone. There is no pulling back once you are in the ring, this space designed for fighting. You can count only on yourself. Compulsively, the gestures become automatic. Now, on a project, I act as if in the ring" [10, p. 41].

${ }^{20}$ In a September 2018 letter to the Turin architect Alessandro Armando (who wrote a book on the project as document, opposing the intentionality of the architect and the myth of interiority), architect Peter Eisenman writes: "I think my idea of bottega is different. For me bottega is in my head." The atelier, the studio, the laboratory or boutique - since etymologically bottega is a place (un luogo) meant for storing sundry objects - is above all in the architect's head. What are these objects or object in the head? The title of the Serbo-Croatian translation of Peter Eisenman's collection of texts was "Idealni objekt arhitekture" [The Ideal 
Derrida's sentence from "Introduction to Husserl's Origin of Geometry," "the ideal object is the absolute model of the object in general" (l'objet idéal est le modèle absolu de lobjet en général) [11, p.57] implies that this ideal is actually regulative and opposed to objects not purely intentional or objects that are intentional cum fundamento in re (a distinction we borrow from Roman Ingarden), or opposed to ordinary physical objects (which Peter Eisenman also calls "things in themselves"). Levinas' book on intuition in Husserl contains the phrase "une structure idéale de l'objet" [12, p.117] and it displays rather well the nature of the ideal. The head (Bergson's or Eisenman's or whoever) does not contain objects (this would be nonsense), nor even the ideal or ideas (for this would be trivial - everyone has ideas, heads are brimming with ideas, meaning that the explanation is insufficient). Rather, it contains the 'ideal of the object as such.' The idea of something that has physical presence is precisely the conceptual or the concept. In his famous text on conceptual architecture, Eisenman finds that "the idea within the thing itself" is synonymous to "conceptual structure" of the thing itself, and finally that "the physical reality itself does have a conceptual aspect." What is the novelty here? Projecting (throwing forward, pitching) is not projecting/designing an object (one does not throw forward an object). The object is, rather, discovered, revealed, selected, exposed, presented before (vis-à-vis; Gegenstand) by way of concept. In that sense, the project is a projection of the concept that is always the concept of the object (the 'ideal of the object as such'). The task of architecture is to reveal the concepts of physical things and realize objects in time (process and design are two protocols that only appear at this point). The task of philosophy is to prepare and explain this.

\section{References}

1. Losoncz, M. (2017), Phenomenologies of Empty Intentionality. Filozofska istraživanja, vol.37, is. 3, pp. 529-544.

2. Libera, A. de (1999), L’art des Généralités Théories de L'Abstraction, Aubier, Paris, 703 p.

3. Kojève, A. (2014), The Notion of Authority, Verso Books, London, $224 \mathrm{p}$.

4. Krueger, J. (2011), Extended cognition and the space of social interaction, Consciousness and Cognition, vol. 20, is. 3, pp. 643-657.

5. Simmel, G. (1995), Aufsätze und Abhandlungen 1901-1908, Bd.1, Simmel, G.Gesamtausgabe, vol. 7, Suhrkamp, Frankfurt am Main, 382 p.

6. Simmel, G. (1992), Untersuchungen über die Formen der Vergesellschaftung, in Simmel, G., Gesamtausgabe, vol. 11, Suhrkamp, Frankfurt am Main, 1051 p.

7. Kant, I. (1999), Critique of Pure Reason, Cambridge University Press, Cambridge, 785 p.

8. Bergson, H. (2016), Histoire de l'idée de temps. Cours au Collège de France 1902-1903, PUF, Paris, $408 \mathrm{p}$.

9. Bataille, G. (1973), Lexpèrience intèrieure, in Bataille, G., Oevres complètes, vol. 5, Gallimard, Paris, pp.7-181.

10. Enjalbert, C. (2017), "Entretien avec Tadao Ando", Philosophie magazine, no. 114, pp.39-43.

11. Derrida, J. (1962), “Introduction”, in Husserl, E., L'Origine de la Géométrie, PUF, Paris, pp.3-173.

12. Levinas, E. (1930), Théorie de l'intuition dans la phénoménologie de Husserl, Vrin, Paris, 224 p.

Received: October 2, 2019

Accepted: December 11, 2019

Object of Architecture]. Lest we forget, "ideal object" or "ideality of the architectural object" (and Peter's text "Misreading Eisenman" contains the phrase "the object as ideal essence," as well as a differentiation made a few years ago in Belgrade between "object as a mental construct" and "the actual object") is actually a paraphrase of the title of Jacques Derrida's 1957 unwritten doctoral thesis, "The Ideality of Literary Object" (l'idealité de l’objet litteraire). 
Authors' information:

Petar Bojanić - Dr. Sci. in Philosophy, Professor, Leading Researcher; bojanicp@gmail.com

Ekaterina S.Cherepanova - Dr. Sci. in Philosophy, Professor; e.s.cherepanova@urfu.ru

\title{
Изобретение будущего во временном проекте. Воображаемая «встреча» Георга Зиммеля и Анри Бергсона и ее значение для архитектуры
}

\author{
П. Боянич ${ }^{1,2}$, Е. С. Черепанова ${ }^{2}$ \\ ${ }^{1}$ Белградский университет, \\ Сербия, 11000, Белград, ул. Кральице Наталье, 45 \\ 2 Уральский федеральный университет им. первого Президента России Б.Н.Ельцина, \\ Российская Федерация, 620083, Екатеринбург, пр. Ленина, 51
}

Для цитирования: Bojanić P., Cherepanova E. S. Invention of the future in project-time. An imaginary "encounter" between Georg Simmel and Henri Bergson, and its significance for architecture // Вестник Санкт-Петербургского университета. Философия и конфликтология. 2020. Т. 36. Вып. 1. С. 131-140. https://doi.org/10.21638/spbu17.2020.111

В статье рассматриваются в реконструированном диалоге тексты Г.Зиммеля («Untersuchungen über die Formen der Vergesellschaftung»; «Über räumliche Projekten sozialer Formen») и А. Бергсона («Histoire de l'idée de temps») с целью проанализировать вопрос о том, как понималось проектирование/создание будущего этими философами и как можно трактовать его сегодня. Авторам хотелось бы представить некоторые условия и трудности раскрытия будущего и временного характера любого проекта. Также мы бы хотели показать недостаточность языков, на которых говорит большое количество людей, заключающееся в том, что будущее трудно лингвистически стабилизировать и задокументировать: немецкий и английский языки не имеют будущего времени, используя вместо этого вспомогательные глаголы «werden» (стать), «will»/«be going to». Исследование проекта как интеллектуального (замысел, идея, концепт) и социального (проектирование как социальное действие) феномена позволяет показать, каким образом будущее (проект) становится задачей деятельности в настоящем. Проект переносит или сдвигает (Зиммель) будущее в пространство, которое всегда готово к восприятию проекций, и является также возможностью организации будущих совместных действий. Мы попытаемся доказать, что когда проект выполнен, больше нет ни проекта, ни будущего. Таким образом, проект обеспечивает будущее. Чтобы рассуждения не выходили за пределы логического круга, мы введем третий элемент: без будущего группа, или «мы», не может существовать. Авторы хотели бы показать, что идея проекта или, возможно, набросок любой будущей теории проекта (или концепции) уже были представлены в начале прошлого века в рамках воображаемой встречи Анри Бергсона и Георга Зиммеля.

Ключевые слова: проект, время, будущее, Анри Бергсон, концепт.

Статья поступила в редакцию 2 октября 2019 г.; рекомендована в печать 11 декабря 2019 г.

Контактная информация:

Боянич Петар - д-р философии, проф., вед. науч. сотр.; bojanicp@gmail.com Черепанова Екатерина Сергеевна - д-р филос. наук, проф.; e.s.cherepanova@urfu.ru 